\title{
ASPEK BIOLOGI DAN DAERAH PENANGKAPAN CUCUT BOTOL (Squalus sp.) YANG TERTANGKAP DI PERAIRAN SAMUDERA HINDIA
}

\author{
Dharmadi'1) dan Fahmi²) \\ 1) Peneliti pada Pusat Riset Perikanan Tangkap, Ancol-Jakarta \\ 2) Peneliti pada Pusat Penelitian Oseanografi-Lembaga IImu Penelitian Indonesia, Ancol-Jakarta
}

\begin{abstract}
ABSTRAK
Penelitian mengenai keragaman jenis Elasmobranchi dilakukan pada bulan Januari sampai dengan Desember 2002 di pelabuhan-pelabuhan perikanan PPI Cilacap, TPI Palabuhanratu, TPI Kedonganan-Bali, dan PPI Tanjung Luar-Lombok Timur. Cucut botol Squalus sp. merupakan jenis cucut laut dalam yang paling sering dijumpai selama penelitian berlangsung. Hasil penelitian menunjukkan bahwa cucut botol betina lebih sering tertangkap dibandingkan cucut jantan pada setiap waktu pengamatan. Frekuensi panjang cucut botol tertinggi dijumpai pada bulan Juni dan Agustus yaitu berkisar antara 62 sampai dengan $68 \mathrm{~cm}$. Nisbah kelamin cucut botol antara jantan betina selama pengamatan adalah 1:1,83. Hubungan antara panjang total tubuh dan panjang klasper cenderung linier dengan nilai $R^{2}=0,634326$. Puncak musim penangkapan cucut botol terjadi sekitar bulan Agustus. Sedangkan daerah penangkapan cucut botol adalah di perairan Samudera Hindia.
\end{abstract}

KATA KUNCI: biologi, daerah penangkapan, cucut botol, Samudera Hindia

ABSTRACT: Biological aspects and fishing ground of dog fish shark (Squalus sp.) caught in Indian Ocean waters. By: Dharmadi and Fahmi

A study on diversity Elasmobranchi of was conducted using market surveys method from January to December 2002 at several fish landings in southern Indonesia, i.e. the Cilacap, Palabuhanratu, KedongananBali, and Tanjung Luar-East Lombok landing sites. A deep water shark, Indonesian shortnose spurdog (Squalus sp.), was the most common deep water sharks captured in the area during the study. Results show that females sharks were caught more frequent at every observation than those of males. The most abundant of Indonesian shortnose spurdog was recorded in June and August ranging from 62 to $68 \mathrm{~cm}$ in total length. Sex ratio between males and females of Squalus sp. during the study was 1:1.83, and the relationship between total length and claspers length of dogfish shark was linier $\left(R^{2}=0.634326\right)$. The peak fishing season of Indonesian spurdog was occurred in August with the fishing area was in the Indian Ocean.

\section{KEYWORDS: $\quad$ biology, fishing ground, dog fish shark, Indian Ocean}

\section{PENDAHULUAN}

Cucut botol (Squalus spp.) merupakan jenis ikan cucut dari suku Squalidae dan termasuk dalam bangsa Squaliformes. Selain Squalidae, terdapat 6 suku lain yang termasuk dalam bangsa Squaliformes, yaitu Echinorhinidae (Bramble sharks), Centrophoridae (Gulper sharks), Etmopteridae (Lantern sharks), Somniosidae (Sleeper sharks), Oxynotidae (Rough sharks), dan Dalatiidae (Kitefin sharks) (Compagno et al., 2005). Di dunia, bangsa Squaliformes diperkirakan terdiri atas lebih dari 106 jenis atau sekitar $21 \%$ dari total jumlah bangsa cucut yang ada di dunia (Compagno, 1990; Compagno et al., 2005).

Cucut botol (dogfish shark) merupakan satu dari beberapa jenis cucut yang mempunyai nilai ekonomis tinggi terutama dari minyak hati. Jenis cucut ini pada umumnya berukuran kecil, dengan panjang total tubuh rata-rata antara 50 sampai dengan $70 \mathrm{~cm}$. Pada beberapa jenis tertentu, ukuran dapat mencapai sampai dengan $200 \mathrm{~cm}$ (Gambar 1).

Jenis ikan ini pada umumnya hidup di perairan dengan kedalaman sekitar $50 \mathrm{~m}$ atau lebih, pada kondisi air yang dingin dengan suhu antara 6 sampai dengan $11^{\circ} \mathrm{C}$. (Castro et al., 1999). Di Indonesia, nama cucut botol dikenal untuk suku Squalidae (marga Squalus) dan Centrophoridae (marga Centrophorus). Marga Squalus tertangkap di perairan Samudera Hindia pada kedalaman mulai dari 50 sampai sekitar $400 \mathrm{~m}$ di daerah slope (lereng benua), sedangkan marga Centrophorus ditemukan pada kedalaman perairan mulai dari 100 sampai dengan lebih dari $2.000 \mathrm{~m}$ (Anonim, 2003). Menurut Compagno (1984), pada umumnya di laut Artik sampai dengan sub Antartik sebagian besar cucut botol dijumpai di dekat perairan dasar dengan kedalaman sekitar 3.675 m bahkan marga Centrophorus tertangkap

Kosrespondensi penulis: 


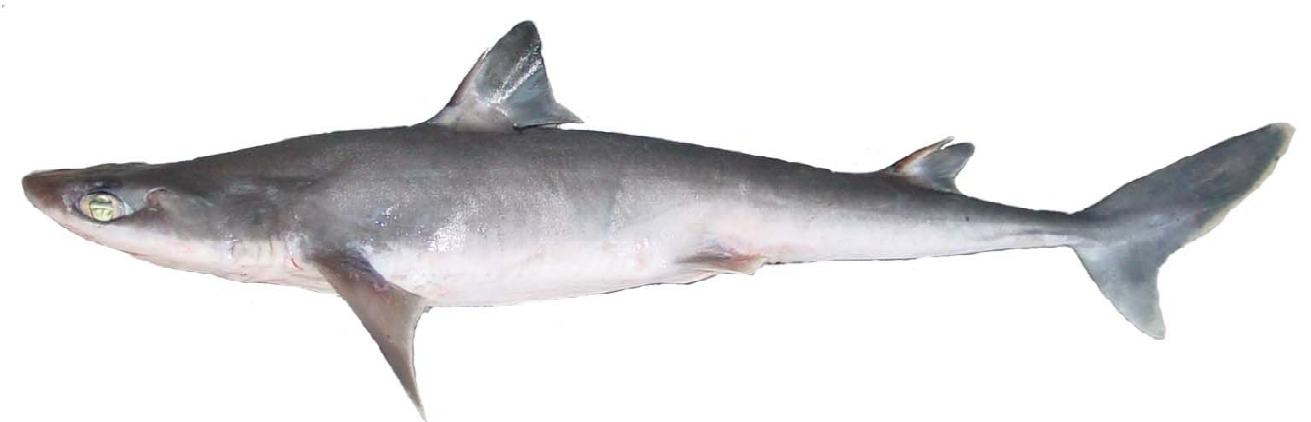

Gambar 1. Cucut botol bermoncong pendek (Squalus sp.). Figure 1. Indonesian shortnose spurdog (Squalus sp.). Koleksi photo/Foto colectted: W.T. White

pada kedalaman lebih dari $6.000 \mathrm{~m}$. Sebagian cucut botol hidup soliter atau memisahkan diri dari kelompok jenis cucut lain. Suku Squalidae bereproduksi secara ovovivipar, artinya dengan cara melahirkan individu baru yang telah berkembang dalam kandungan induk betina. Cucut botol selain memangsa jenis cucut lain juga memangsa cephalopoda (kelompok cumi), krustasea (udang-udangan), dan invertebrata lain bahkan juga mamalia laut (Compagno, 1984).

Cucut botol memiliki bentuk badan agak silindris, di antara sirip dada dan sirip perut terdapat alur yang tidak terlampau nyata. Bentuk mulut bervariasi, ada yang pendek dan tumpul dan ada yang panjang dan lancip, dengan letak mulut ventral atau berada di bawah kepala. Gigi pada rahang atas dan bawah, ada yang berbentuk sama dan ada yang berbeda. Salah satu ciri khas dari jenis cucut botol adalah ada duri keras pada ke-2 pangkal sirip punggung. Ciri lain adalah tidak mempunyai sirip dubur (anal fin) dan bentuk sirip ekor bervariasi. Pada umumnya berwarna abu-abu sampai dengan kehitaman.

Jenis cucut botol (Squalidae) pada umumnya tertangkap di perairan Samudera Hindia dan didaratkan di tempat pendaratan ikan seperti di PalabuhanratuJawa Barat, Cilacap-Jawa Tengah, Kedonganan-Bali, dan Tanjung Luar-Lombok Timur. Ukuran panjang total yang umum tertangkap bervariasi antara 50 sampai dengan $100 \mathrm{~cm}$. Menurut Castro et al. (1999) di dunia terdapat sekitar 42 jenis cucut botol yang tidak boleh dieksploitasi, dan sekitar 43 jenis lain termasuk dalam kategori hampir punah. Selama penelitian, di perairan
Indonesia jenis cucut botol dari suku Squalidae yang ditemukan dan teridentifikasi baru sekitar 5 jenis, dengan 4 jenis diduga merupakan jenis baru yaitu Squalus sp. (philippinensis atau chloroculus), Squalus sp. (edmondsi), Squalus sp., dan Squalus sp. (nasutus). Jenis-jenis tersebut pada umumnya tertangkap dengan rawai dasar dan jaring dasar di Kedonganan-Bali (Dharmadi \& Fahmi, 2003). Jenis cucut botol yang paling sering tertangkap dengan rawai dasar, terutama yang didaratkan di Kedonganan-Bali adalah cucut botol bermoncong pendek (Squalus sp.). Penamaan ilmiah untuk jenis tersebut belum dilakukan karena dalam proses analisis oleh para ahli taksonomi cucut dari Australia. Squalus sp. ini mempunyai ciri spesifik yang berbeda secara morfologi, yaitu bagian ujung belakang sirip punggung ke-2 agak panjang, dengan sisi atas bagian belakang sirip berbentuk huruf $\mathrm{V}$.

Seperti jenis cucut yang lain, cucut botol memiliki karakteristik antara lain berumur panjang, namun pertumbuhan lambat dan berfekunditas rendah (Bonfil, 2002; Camhi et al., 1998; Cavanagh et al., 2003; Coleman, 1996; Ketchen, 1975; Stevens et al., 2000). Jumlah anak yang dilahirkan untuk jenis cucut ini adalah antara 3 sampai dengan 10 ekor. Oleh karena itu, jenis ini rentan terhadap penurunan jumlah populasi di alam bahkan juga rentan terhadap ancaman kepunahan akibat penangkapan yang kurang terkendali.

Sebagai informasi awal dalam mendukung kelestarian sumber daya cucut botol, maka perlu dikemukakan tentang aspek biologi, dan daerah penangkapan. 


\section{BAHAN DAN METODE}

Bahan tulisan ini merupakan bagian dari hasil kegiatan penelitian yang telah dibiayai oleh proyek ACIAR-CSIRO Australia.

Penelitian ini dilakukan pada beberapa tempat pendaratan ikan utama yaitu di PPN Cilacap, PPN Palabuhanratu, TPI Kedonganan-Bali, dan TPI Tanjung Luar-Lombok Timur pada bulan Januari sampai dengan Desember 2002. Pengamatan aspek biologi meliputi pengukuran panjang tubuh (dalam satuan $\mathrm{cm}$ ), nisbah kelamin, serta pengukuran panjang klasper untuk individu jantan. Pengukuran dilakukan secara langsung di lapangan dengan menggunakan pita pengukur dengan ketelitian sampai dengan $0,1 \mathrm{~cm}$. Sedangkan informasi mengenai daerah penangkapan diperoleh dengan cara wawancara langsung dengan para nelayan yang khusus menangkap cucut botol. Data yang dianalisis merupakan data gabungan yang berasal dari ke-4 lokasi pengamatan. Penggabungan data dari ke-4 lokasi tersebut dilakukan dengan asumsi daerah penangkapan dari ke-4 lokasi tersebut dianggap sama, yaitu di perairan Samudera Hindia.

\section{HASIL DAN BAHASAN}

\section{Sebaran Frekuensi Panjang}

Sebaran frekuensi panjang berdasarkan pada jenis kelamin dan waktu pengamatan menunjukkan bahwa cucut botol jenis betina nampak selalu mendominasi pada tiap pengamatan (Gambar 2 dan 3). Pada bulan Maret frekuensi panjang cucut botol betina memiliki sebaran yang relatif merata pada setiap kelas ukuran panjang kecuali pada kelas ukuran antara 40 sampai dengan $47 \mathrm{~cm}$. Berbeda hal dengan kelas ukuran panjang cucut botol jenis jantan, yang memiliki kisaran ukuran yang lebih kecil dan pada ukuran kelas yang lebih besar memiliki frekuensi yang lebih tinggi.

Sebaran frekuensi panjang cucut botol jenis betina pada bulan Juni nampak relatif sedikit berbeda menurut kelas panjang. Sedangkan untuk jenis jantan pada setiap kelas panjang frekuensi relatif sama. Pada bulan Agustus frekuensi setiap ukuran kelas panjang jenis betina terlihat bergeser ke arah kanan dibanding bulanbulan sebelumnya, di mana lebih banyak betina yang tertangkap dengan ukuran yang besar (di atas $55 \mathrm{~cm}$ ) dengan kelimpahan yang tinggi pula. Pada bulan Oktober, jumlah jenis yang tertangkap kembali menurun dengan ukuran yang paling banyak tertangkap pada kisaran 55 sampai dengan $61 \mathrm{~cm}$. Dari jumlah contoh pengamatan terlihat cucut botol betina lebih dominan dan ukuran kelas panjang bervariasi berdasarkan pada waktu. Secara umum, kisaran ukuran panjang ikan betina lebih luas dari pada ikan jantan. Ukuran tubuh betina tercatat antara 40 sampai dengan $73 \mathrm{~cm}$, sedangkan pada ikan jantan hanya berkisar antara 43 sampai dengan $66 \mathrm{~cm}$. Hal ini, menunjukkan bahwa ikan betina dapat mencapai ukuran yang lebih besar dari pada jantan. Kondisi tersebut ditemukan pada ikan cucut, di mana ikan cucut betina dapat mencapai ukuran yang lebih besar dari pada jantan (Lucifora et al., 1999; Saunder \& Gordon, 1993; Watson \& Smale, 1998). Selain itu, kisaran ukuran cucut botol pada bulan Maret lebih besar dibanding kisaran ukuran pada bulan Oktober, di mana kisaran ukuran tubuh Squalus sp. makin menyempit, dengan puncak kelimpahan jenis ini terjadi di bulan Agustus untuk ikan betina, sedangkan pada ikan jantan terjadi di bulan Maret. Seperti pada umumnya jenis cucut yang lain, cucut botol betina tumbuh dan mencapai dewasa pada ukuran yang lebih besar daripada ikan jantan. Sebagai contoh, jenis cucut botol Squalus megalops betina dapat mencapai panjang total tubuh sampai dengan $782 \mathrm{~mm}$, sedangkan ikan jantan hanya sampai dengan $572 \mathrm{~mm}$ (Watson \& Smale, 1998).

Ukuran kelas panjang menggambarkan pertumbuhan pada suatu individu jenis. Menurut Sparre \& Venema (1999) frekuensi kelompok ukuran kelas panjang dapat digunakan untuk menentukan umur atau ditujukan untuk memisahkan suatu distribusi frekuensi panjang yang kompleks ke dalam kohort atau kelompok umur ikan. Meskipun data frekuensi panjang cucut botol relatif sama atau bahkan terjadi perbedaan berdasarkan pada waktu pengamatan namun diduga berdasarkan pada kelompok kelas panjang, cucut botol tersebut terdiri atas kelompok umur yang berbeda. Namun, demikian diperlukan analisis yang lebih akurat disertai dengan data yang lebih lengkap untuk menentukan kelompok umur cucut botol. Menurut para ahli adalah tidak mudah untuk menentukan umur dari ikan-ikan tropis, oleh karena itu analisis data frekuensi panjang dengan sejumlah metode tertentu menurut Bhattacharya (1967); Sparre et al. (1989) dapat digunakan untuk menentukan umur terhadap kelompok-kelompok panjang tertentu. 

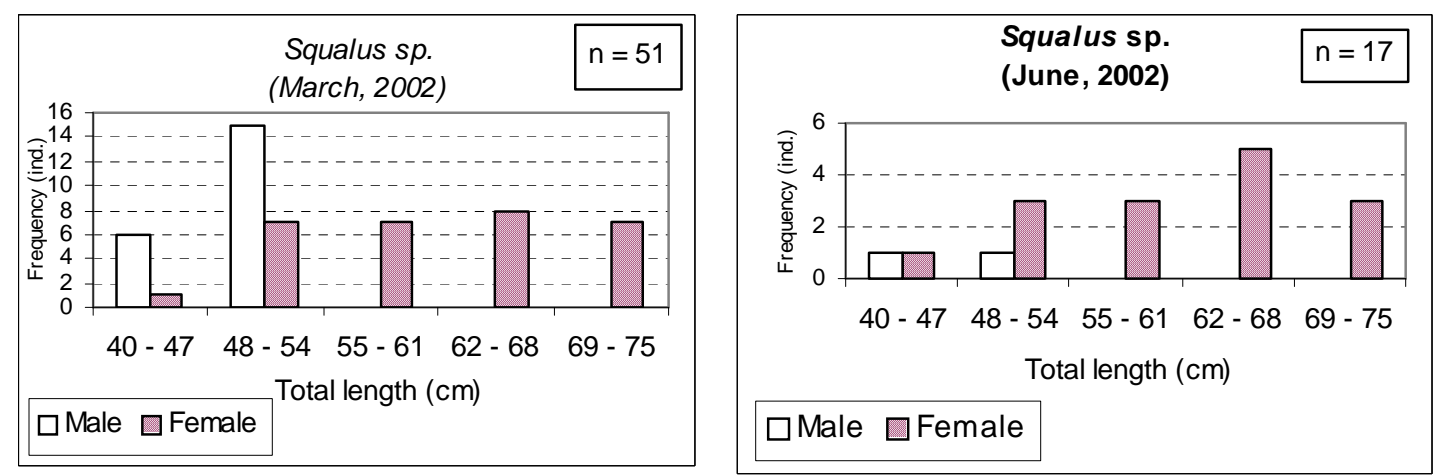

Gambar $2(a, b)$.

Frekuesi panjang cucut botol jantan dan betina bulan Maret dan Juni 2002.

Figure $2(a, b)$.

Length frequency of dogfish shark (male and female) on March and June 2002.
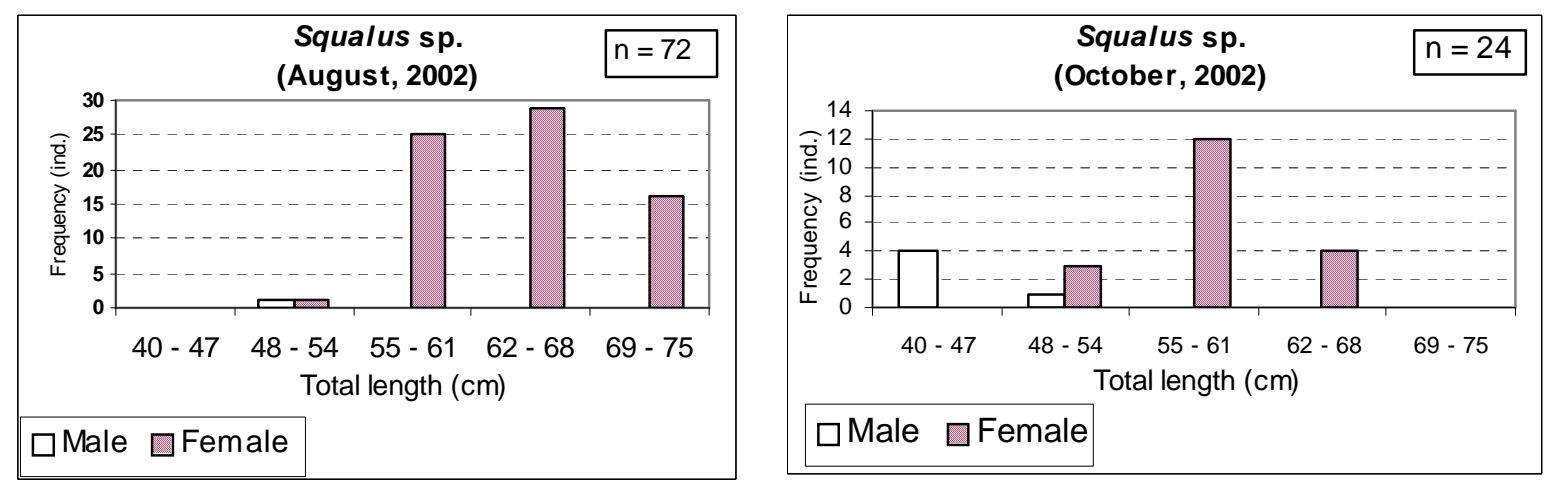

Gambar $3(a, b)$.

Frekuesi panjang cucut botol jantan dan betina bulan Agustus dan Oktober 2002. Figure $3(a, b)$. Length frequency of dogfish shark (male and female) on March and June 2002.

\section{Nisbah Kelamin}

Nisbah kelamin cucut botol yang tertangkap di 3 lokasi tersebut di atas antara jenis jantan dan betina adalah 1:1,83 (Gambar 4). Berdasarkan pada uji Chi kuadrat, rasio antara jantan dan betina berbeda nyata dengan rasio ideal 1:1 $\left(\chi^{2}=51,7 ; P>0,05\right)$.

Nilai tersebut menunjukkan bahwa jumlah cucut botol jenis betina lebih banyak tertangkap di perairan Samudera Hindia. Hal ini, dapat mengindikasikan 2 hal, yang ke-1 adalah jumlah individu betina di alam cenderung lebih besar daripada ikan jantan. Ke-2, hal ini juga dapat berarti ikan betina lebih mudah tertangkap dibanding ikan jantan apabila diasumsikan perbandingan populasi betina dan jantan yang ada di alam sama. Sehingga, nilai perbandingan yang diperoleh belum memberikan gambaran seperti yang diharapkan dalam mendukung proses rekruitmen jenis di suatu perairan. Agar rekruitmen jenis berlangsung dengan baik dan populasi dapat stabil, maka perbandingan jantan betina yang ideal adalah 50:50 (B. Sumiono, Komunikasi langsung). Dengan demikian, dapat diasumsikan pula bahwa ikan betina cenderung lebih rentan terhadap ancaman kepunahan dibanding ikan jantan apabila mengalami tangkap lebih (over fishing), karena ikan betina lebih mudah tertangkap dan tidak memiliki kesempatan untuk bereproduksi sehingga proses rekruitmen tidak terjadi.

Apabila telah mengalami tangkap lebih (over fishing), maka akan sangat sulit bagi cucut untuk memulihkan kembali populasi karena karakteristik ikan cucut yang khas, yaitu berumur panjang, siklus reproduksi yang lama dan jumlah anak yang dihasilkan relatif sedikit yaitu antara 2 sampai dengan 4 embrio per ekor. Sebagai contoh, untuk jenis Squalus acanthias kematangan kelamin (mature) paling muda dicapai pada umur 24 tahun dengan kisaran panjang antara 93,4 sampai dengan $94,4 \mathrm{~cm}$, bahkan pada umur paling tua, yaitu 62 tahun ada yang tidak mengalami kematangan kelamin (immature) (Mark \& Gordon, vide Demski \& Wourms, 1993). Sedangkan Ketchen (1975) menduga bahwa rata-rata kematangan kelamin betina cucut botol 
(Squalus acanthias) secara individu dicapai pada umur 34 sampai dengan 38 tahun dan secara kelompok umur (cohort) mencapai 32 tahun. Bonham et al. (1949) menduga bahwa di perairan Lautan Pasifik bagian utara, $50 \%$ dari populasi betina dari jenis yang sama $\left(L_{50}\right)$ mencapai kematangan seksual kelamin pada umur antara 20 sampai dengan 34 tahun. Untuk mengetahui pada umur berapa jenis Squalus sp. 3 atau jenis cucut botol lain yang ditemukan di Indonesia selama penelitian ini mencapai tingkat kematangan kelamin, diperlukan data yang runtun waktu dan berkesinambungan.
Kematangan kelamin ikan pada dasarnya dipengaruhi oleh beberapa faktor. Menurut Saunder \& Gordon (1993) bahwa stres lingkungan seperti perubahan ketersediaan makanan, menyebabkan pertumbuhan lebih lambat untuk populasi cucut yang matang kelamin pada ukuran lebih kecil dan sebaliknya pertumbuhan lebih cepat pada populasi cucut yang matang kelamin yang berukuran lebih besar, ini berarti bahwa terdapat hubungan erat antara faktor lingkungan dan ukuran pada proses pertumbuhan terhadap cucut yang mengalami kematangan kelamin.

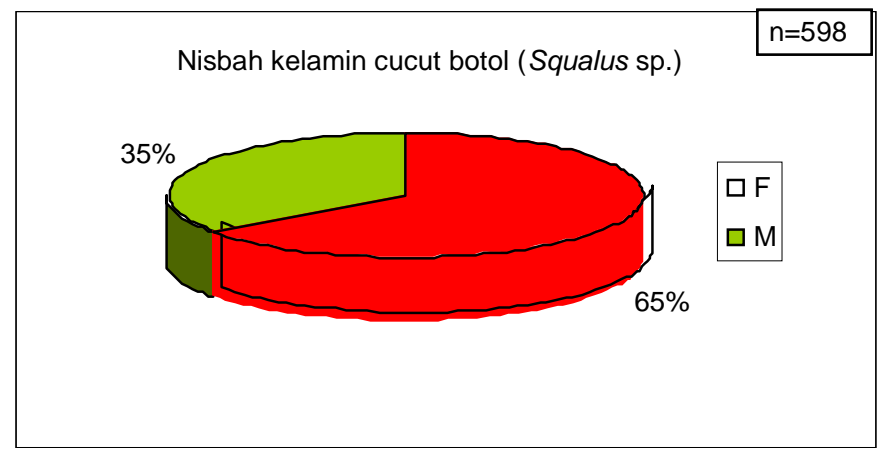

Gambar 4.

Nisbah kelamin cucut botol.

Figure 4. Sex ratio of Indonesian shortnose spurdog (Squalus sp.).

\section{Hubungan Panjang Total dengan Panjang Klasper}

Tingkat kematangan jenis kelamin jantan dapat dibedakan berdasarkan pada keadaan klasper yang terbagi dalam 3 tingkatan yaitu:

1. Klasper yang belum berisi atau belum mengandung kapur (not calcified), di mana ukuran klasper relatif kecil dan bila ditekan terasa lunak.

2. Klasper yang telah berisi sebagian zat kapur (not full calcified), di mana klasper berukuran sedang dan belum penuh mengeras.

3. Klasper yang telah penuh berisi zat kapur (full calcified), di mana seluruh bagian klasper dari pangkal sampai dengan ujung klasper dalam kondisi mengeras dan berukuran lebih besar (Dharmadi et al., 2003).

Selama pengamatan di lapangan, klasper cucut botol yang dijumpai sebagian besar dalam kondisi full calcified. Kondisi klasper seperti ini sebagian besar dijumpai pada bulan Juni, di mana ukuran klasper pada periode tersebut lebih panjang dan dalam kondisi mengeras dibanding bulan Maret dan Oktober. Besar kecil ukuran klasper dapat menggambarkan suatu dugaan musim pemijahan. Klasper cucut botol yang berukuran besar dan dalam kondisi mengeras banyak dijumpai pada bulan Juni, hal ini mengindikasikan bahwa kemungkinan proses pemijahan dapat berlangsung sekitar bulan Juni hingga Juli, ketika baik jantan maupun betina mencapai kematangan seksual. Gambar 5 menunjukkan bahwa hubungan antara panjang total tubuh dengan panjang klasper nampak selalu berbanding lurus, yang berarti bahwa pertambahan panjang total tubuh berpengaruh positif terhadap perkembangan panjang klasper cucut botol. Hasil pengamatan di lapangan pada bulan Juni telah terjadi proses pengerasan klasper atau terjadi kematangan alat kelamin jantan dari cucut botol dan bersamaan dengan waktu tersebut juga dijumpai embrio pada cucut botol betina, baik pada bulan Juni maupun Agustus. Mekanisme terjadi proses kopulasi atau perkawinan antara cucut jantan dan betina dijelaskan oleh Dodd et al. (1982) yaitu sebagai berikut klasper bagian kiri akan bergerak menyilang ke arah klasper bagian kanan sampai dengan membentuk sudut $90^{\circ}$, kemudian klasper kiri dimasukan ke dalam kloaka betina, sedangkan klasper bagian kanan tetap pada posisi lurus dan normal. Setelah selama 20 menit pasangan cucut tersebut badan seolah-olah tidak bergerak tetapi kepala bergerak sampai dengan mencapai setengah lingkaran atau $180^{\circ}$. 


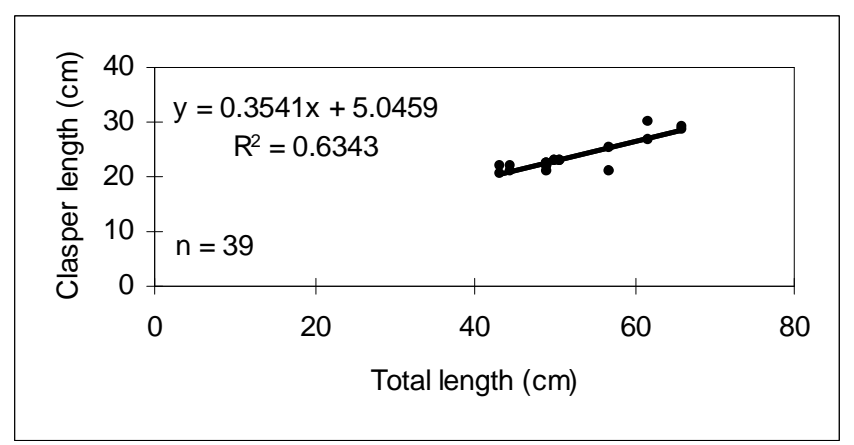

Gambar 5. Hubungan antara panjang total tubuh dan panjang klasper cucut botol (Squalus sp.). Figure 5. Relationship between total and outer clasper lengths of dogfish shark (Squalus sp.).

\section{Daerah Penangkapan}

Daerah penangkapan cucut botol berdasarkan pada hasil wawancara dengan para nelayan penangkap cucut botol disajikan pada Tabel 1.

Secara umum, daerah penangkapan cucut botol dari ke-4 lokasi pendaratan ikan tersebut di atas adalah di perairan Samudera Hindia, tetapi secara khusus daerah penangkapan tergantung pada jangkauan armada penangkap ikan dan tempat pendaratan, misal di Pelabuhanratu penangkapan cucut botol dilakukan dengan menggunakan pancing rawai dasar yang dioperasikan di perairan sekitar Pelabuhanratu dengan jarak kurang lebih 10 mil dari pantai pada kedalaman antara 150 sampai dengan 200 m. Di Cilacap penangkapan cucut botol dilakukan dengan menggunakan jaring insang dasar yang dioperasikan di perairan yang jaraknya sekitar 5 sampai dengan 10 mil dari pantai yaitu di daerah perairan Gombong dan Cikaso pada kedalaman antara 40 sampai dengan 60 $\mathrm{m}$. Di Kedonganan-Bali, nelayan menangkap cucut botol dengan menggunakan pancing rawai dasar, daerah penangkapan di bagian selatan Bali yang jarak sekitar 5 sampai dengan 10 mil dari Pantai Padang Bukit pada kedalaman antara 100 sampai dengan $150 \mathrm{~m}$. Sedangkan nelayan di Tanjung Luar-Nusa Tenggara Barat melakukan penangkapan cucut botol dengan menggunakan pancing rawai dasar yang dioperasikan di sekitar perairan Pulau Sumba, Pulau Sarage, Pulau Sembilan, Pulau Sabahuna, Pulau Larantuka, Pulau Dana, dan Pulau Rajua pada kedalaman antara 100 sampai dengan $150 \mathrm{~m}$ (Tabel 1).

Daerah penangkapan cucut botol tersaji pada Gambar 6.

Tabel 1. Daerah penangkapan cucut botol berdasarkan pada lokasi dan tipe alat tangkap Table 1. $\quad$ Fishing ground of dog fish shark depend on location and gear tipe

\begin{tabular}{|c|c|c|}
\hline Lokasi & Tipe alat tangkap & Daerah penangkapan \\
\hline Pelabuhanratu & Pancing rawai dasar & $\begin{array}{l}\text { Perairan sekitar } 10 \text { mil dari pantai } \\
\text { Palabuhanratu pada kedalaman } 150 \text { sampai } \\
\text { dengan } 200 \mathrm{~m} \text {. }\end{array}$ \\
\hline Cilacap & Jaring insang dasar & $\begin{array}{l}\text { Perairan sekitar } 5 \text { sampai dengan } 10 \text { mil dari } \\
\text { Pantai Gombong, Cikaso pada kedalaman } 40 \\
\text { sampai dengan } 60 \mathrm{~m} \text {. }\end{array}$ \\
\hline Kedonganan-Bali & Pancing rawai dasar & $\begin{array}{l}\text { Perairan bagian selatan Bali sekitar } 5 \text { sampai } \\
\text { dengan } 10 \text { mil dari Pantai Padang Bukit pada } \\
\text { kedalaman } 100 \text { sampai dengan } 150 \mathrm{~m} \text {. }\end{array}$ \\
\hline Tanjung Luar-Nusa Tenggara & Pancing rawai dasar & $\begin{array}{l}\text { Perairan sekitar } 10 \text { mil dari Pulau Sumba, } \\
\text { Pulau Sarage, Pulau Sembilan, Pulau } \\
\text { Sabahuna, Pulau Larantuka, Pulau Dana, } \\
\text { Pulau Rajua pada kedalaman } 100 \text { sampai } \\
\text { dengan } 150 \mathrm{~m} \text {. }\end{array}$ \\
\hline
\end{tabular}




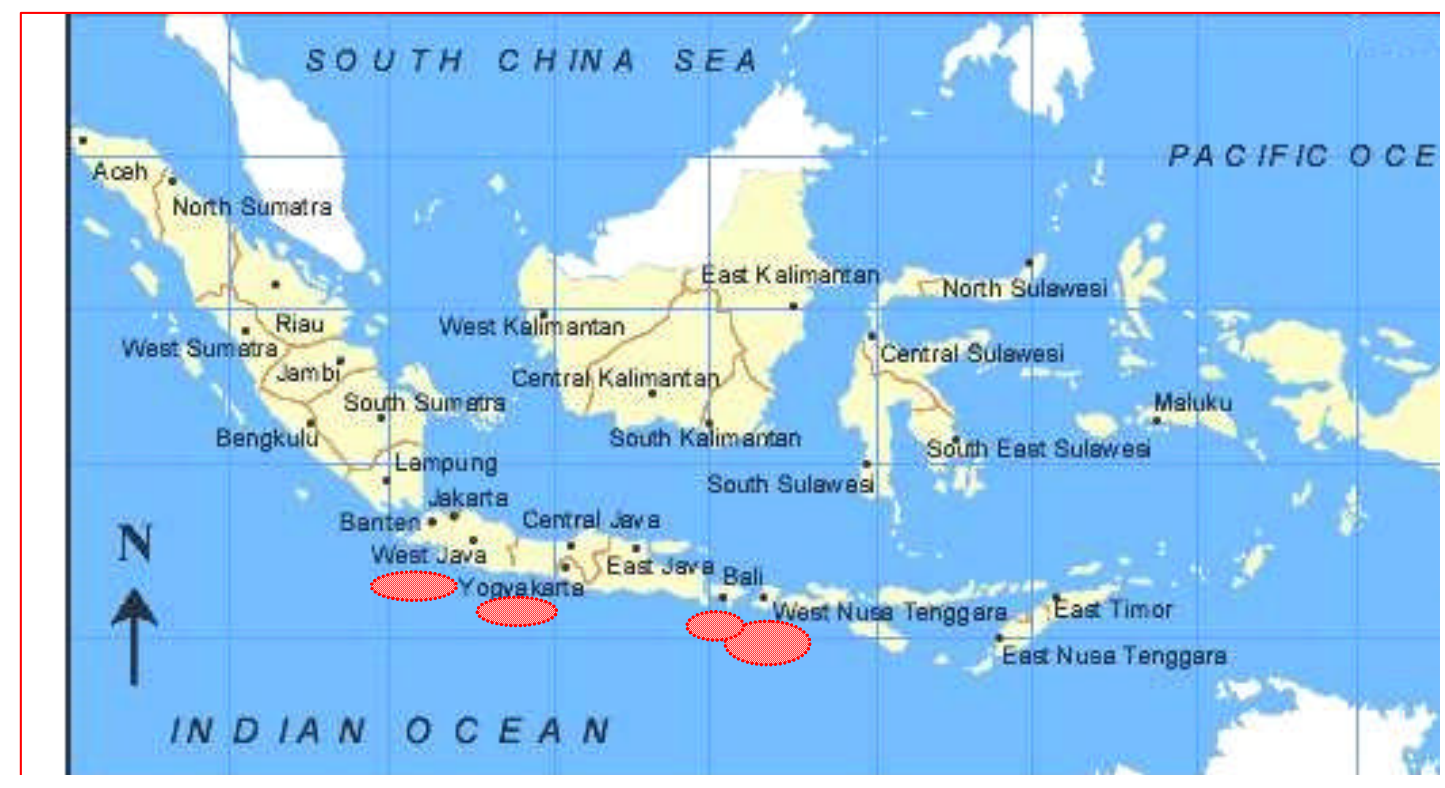

Gambar 6. Daerah penangkapan cucut botol di perairan Samudera Hindia.

Figure 6. $\quad$ Fishing ground of dogfish sharks in Indian Ocean waters.

\section{KESIMPULAN}

1. Sebaran kelas panjang cucut botol yang tertangkap di perairan Samudera Hindia berkisar antara 40 sampai dengan $75 \mathrm{~cm}$, didominasi oleh ukuran 62 sampai dengan $68 \mathrm{~cm}$.

2. Musim pemijahan cucut botol diduga terjadi pada sekitar bulan Juni sampai dengan Juli yang ditandai dengan kematangan kelamin jantan dan betina pada periode tersebut.

3. Meskipun cucut botol tertangkap hampir setiap bulan tetapi diperkirakan musim penangkapan terjadi sekitar bulan Juni sampai dengan September dan puncak terjadi pada bulan Agustus.

4. Cucut botol tertangkap pada kedalaman antara 50 sampai dengan $200 \mathrm{~m}$ di perairan Samudera Hindia.

\section{Persantunan}

Hasil dari kegiatan riset: Artisanal Shark and Ray Fisheries in Eastern Indonesian: Their Sosio Economic and Fisheries Characterictics and Relationship with Australian Resources T.A. 2001 di Australian Centre for International Agriculture Research

\section{DAFTAR PUSTAKA}

Anonim, 2003. Artisanal shark and ray fisheries in east Indonesia: their socio economic and fishery characteristics and relationship to Australian resources. Second Annual Report. FIS 2000/062. $73 \mathrm{p}$.

Bhattarcharya, C. G. 1967. A simple method of resolution of a distribution into Gaussian components. Biometrics. 23: 115-135.

Bonfil, R. 2002. Trends and patterns in world and Asian elasmobranch fisheries. In Fowler S. L., T. M. Reed, \& F. A. Dipper (Eds). Elasmobranchi biodiversity, conservation, and management. Proceedings of the International seminar and Workshop, Sabah, Malaysia, July 1997. IUCN SSC Shark Specialist Group. IUCN. Gland. Switzerland and Cambridge. UK. pp: 15-24.

Bonham, K., F. B. Sanford, W. Clegg, \& G. C. Bucher. 1949. Biological and vitamin A studies of dogfish landed in the State of Washington (Squalus suckleyi). Wash. Dept. Fish. Biol. Bull. 49 A: 83-113.

Camhi, M., S. Fowler, J. Musick, A. Brautigam, \& S. Fordham. 1998. Sharks and their Relatives-Ecology and Conservation. IUCN/SSC Shark Specialist Group. IUCN. Gland. Switzerland and Cambridge. UK. iv+39 pp. 
Castro, J. I., C. M. Woodley, \& R. L. Brudek. 1999. A preliminary evolution of the status of shark species. National oceanographic and atmospheric administration. National Marine Fisheries Service Southeast Fisheries Science Center Miami, Florida. USA. FAO. Fisheries Technical Paper No.380.

Cavanagh, R. D., P. M. Kyne, S. L. Fowler, J. A. Musick, \& M. B. Bennett (eds). 2003. The conservation status of Australasian chondrichthyans: Report of the IUCN shark specialist group Australia and oceania regional red list workshop. Queensland. Australia. 7-9 March 2003. The University of Queensland. School of Biomedical Sciences. Brisbane. 170 p.

Coleman, N. 1996. Australia's Sharks and Rays. National Book Distributors and Publishers. NSW Australia. $61 \mathrm{p}$.

Compagno, L. J. V. 1984. FAO jenis catalogue. Vol.4. Sharks of the world. An annotated and illustrated catalogue of sharks jenis known to date. Part 1. Hexanchiformes to Lamniformes. FAO Fish. Synop. (125) Vol.4. Pt 1: 249 p.

Compagno, L. J. V. 1990. Alternative life-history style of cartilaginous fishes in time and space. Environmental Biology of Fishes 28: 33-75. 1990. Kluwer Academic Publisher. Netherlands.

Compagno, L. J. V., M. Dando, \& S. Fowler. 2005. Sharks of the world. Priceton University Press. New'Jersey. $368 \mathrm{p}$.

Demski, L. C. \& J. P. Wourms. 1993. The reproduction and development of sharks, skates, rays, and ratfishes. Kluwer Academic Publishers. Netherlands. 299 p.

Dharmadi, Maria M. W., \& Anung W. 2003. Morfologi, habitat, dan biologi cucut marga Alopias. Warta Penelitian Indonesia Edisi Sumber Daya dan Penangkapan. Vol.9 No.5. 2003. hal. 20-25.

Dharmadi \& Fahmi. 2003. Fisheries characteristics of artisanal sharks and rays in Indonesia waters. Papers International Seminar on Marine and Fisheries. 1516 December. Agency for Marine and Fisheries Research. Ministry of Marine Affairs and Fishery. $p$ 122-129.
Dodd J. M., M. H. Dodd, \& R. T. Duggan. 1982. Control of reproduction in elasmobranchi fishes. Crom Helm London and Canberra.

Ketchen, K. S. 1975. Age and growth of dogfish (Squalus Acanthias) in British Colimbia waters. Journal Fisheries Researce. Board Canada. 32: 43-59.

Lucifora, L. O., J. L. Valero, \& V. B. Garcia. 1999. Length at maturity of the greeneye spurdog shark, Squalus mitsukurii (Elasmobranchii: Squalidae), from the SW Atlantic, with comparisons with other regions. Mar. Freshwater Res. 50: 629-632.

Saunders, M. W. \& Gordon A. M. 1993. Age and length a-maturity of the female spiny dogfish, Squalus acanthias, in the Strait of Georgia, British Columbia, Canada. Environmental Biology of Fishes. 38: 4957. 1993. Kluwer Academic Publishers. Netherlands.

Sparre, P., E. Ursin, \& S. C. Venema. 1989. Introduksi pengkajian stok ikan tropis. Buku I: Manual. FAOPusat Penelitian dan Pengembangan PerikananBadan Penelitian dan Pengembangan Pertanian. 438 hal.

Sparre, P. \& S. C. Venema. 1999. Introduksi pengkajian stok ikan tropis. Edisi Bahasa Indonesia. Pusat Penelitian dan Pengembangan Perikanan. 438 hal.

Stevens, J. D., Bonfil R., Dulvy N. K., \& Walker P. A. 2000. The effects of fishing on sharks, rays, and chimaeras (chondrichthyans), and the implications for marine ecosystem. ICES Journal of Marine Science. 57: 476-494.

Watson, G. \& M. J. Smale. 1998. Reproductive biology of shortnose spiny dogfish, Squalus megalops, from the Agulhas Bank. South Africa. Mar. Freshwater Res. Vol.49. 695-703.

Watson, G. \& M. J. Smale. 1999. Age and growth estimates of the shortnose spiny dogfish, Squalus megalops, from the Agulhas Bank. South Africa. South African Journal of Marine Science. Vol.21.

Widodo, J. 2002. Pengantar pengkajian stok ikan. Pusat Riset Perikanan Tangkap. Badan Riset Kelautan dan Perikanan. Departemen Kelautan dan Perikanan. 16 hal.

Diterima tanggal: 13 Maret 2006

Diterima setelah perbaikan tanggal: 22 September 2006

Disetujui terbit tanggal: 1 Nopember 2006 